\title{
A outra volta do parafuso: Marcelino Freire
}

Tania Pellegrini. ${ }^{1}$

"A única coisa a fazer com o mundo é suportá-lo."

D. H. Laurence

\section{Violência e crueldade}

“Dizem que sempre falta uma palavra e é verdade. Nesses anos todos eu sei que sim, que sempre falta uma palavra, é verdade" (Freire, 2000: 27). Estas são as primeiras duas linhas de um conto de Marcelino Freire. Roubando-lhe o achado, com que concordo totalmente, decidi todavia juntar mais uma palavra à discussão sobre a centralidade da violência, sobre o gosto pela representação crua da realidade circundante, já de si trágica e brutal, em parte significativa da narrativa brasileira de hoje, de que Freire é reconhecido representante .

Refletindo sobre os tantos autores que se dedicam a esse tipo de representação, aos poucos percebi uma espécie de gradação nos modos de capturar a matéria do real, com várias nuances, evoluindo da violência para a crueldade. No meu modo de entender, violência é sinônimo de brutalidade; implicando força, ímpeto, intensidade, vem a ser abrupta, aberta, escancarada, sendo que o sujeito e o objeto dela podem se aniquilar mutuamente; já a crueldade requer sutileza na aplicação, cuidado nas minúcias, argúcia na escolha dos métodos, apuro e cálculo na elaboração, em suma, mais uma volta no parafuso; a primeira em geral produz espanto, medo e horror, a segunda, além disso, causa repulsa e incredulidade. Assim, a violência viria primeiro, a crueldade depois; melhor, a violência conteria em si a crueldade, seu maior requinte; ou

\footnotetext{
${ }^{1}$ Professora Associada da Universidade Federal de São Carlos. Tem experiência na área de Teoria da Literatura, Literatura Brasileira e Sociologia, com ênfase em Sociologia da Cultura e da Literatura.
} 
ainda, a crueldade poderia ser consequência voluntária da violência. Seja como for, convém assim dizer que o limiar entre ambas, tanto nos atos que denominam, quanto na sua própria denominação, é tênue; mas para os fins a que se destina essa tentativa de identificação, mais que de objetividade, acredito que basta, por enquanto.

Relacionada à semântica da violência e da crueldade, é usual também usar sadismo, e, grosso modo, de acordo com inúmeros estudiosos das mais diferentes áreas, foi para demonstrar como o gosto pela crueldade está enraizado na natureza humana, que Sade celebrou acima de tudo o desprezo pelo corpo alheio, o rebaixamento puro e simples do humano, o que traz outra carga de significados ao termo, tangenciando o Mal absoluto e, como consequência, o fascínio que exerce.

No seu livro História da feiura, Umberto Eco lembra que os seres humanos sempre amaram os espetáculos cruéis e as evidências concretas do mal inevitável, desde o tempo dos anfiteatros romanos, e ilustra com imagens e excertos documentais e literários aquilo que define como a "disposição natural" à violência e ao horror, o que induz a sua representação, das mais diferentes formas, ao longo dos séculos, fugindo das idealizações ligadas à beleza e à harmonia. Enfatiza que Schiller, em Da arte trágica, de 1792 (Eco, 2007: 220), já apontara claramente essa disposição para o horrível:

É um fenômeno geral na nossa natureza, que aquilo que é triste, terrível e mesmo horrendo nos atraia com um fascínio irresistível; que cenas de dor e terror nos afastem, mas com a mesma força nos atraiam de volta (...) [O que] deve ter, portanto, seu fundamento na disposição natural da alma humana.

Se isso é verdade, a disposição para o horrível, para as "cenas de dor e terror", mescla de prazer e repulsa, seria algo contra o que não se poderia lutar, aproximando-se, de certo 
modo, da atração pelo belo e mesmo pelo sublime, por aquilo que de tão grandioso não pode ser completamente apreendido pela sensibilidade. Claro que hoje dificilmente seria possível utilizar as categorias da harmonia, do belo, do bem e do verdadeiro, importantes na construção da visão romântica, para analisar a arte e a cultura de um mundo hiperreal, em que cresce uma espécie de dessubstancialização narcísica e hostil da matéria humana, tanto na literatura como nas artes visuais.

Talvez grande parte do sucesso que experimenta nos dias de hoje a narrativa dedicada a tematizar tais assuntos possa ser explicada com base nesses argumentos, o dos efeitos da representação da violência e da crueldade em quem dela de alguma maneira compartilha, mas não é enveredar por esse caminho o objetivo deste ensaio, pois isso demandaria outra ordem de investigação. A proposta aqui é assinalar como se articula a organização formal da matéria violenta que a realidade hoje oferece, até atingir a crueldade, examinando textos de ficção contemporânea brasileira, e que funções ela cumpre, além da estética (entendo, obviamente, que função não é a mesma coisa que efeito), considerando que essas funções se manifestam sob certas condições, isto é, em contextos sociais específicos, plenos de situações e formações múltiplas e complexas.

\section{A suficiência do real}

Nessa direção, parto do princípio de que toda ficção, na verdade, estabelece uma espécie de teoria do real, na medida em que é o resultado de um olhar ao mesmo tempo criativo e interpretativo sobre as coisas; assim, faz-se retrato e testemunho, por um lado, mas também criação, por outro, pois as imagens que propõe são recomposições, rearticulações do que retrata e testemunha. Essa teoria do real tem a sua especificidade, que é dada pela natureza do próprio objeto, a realidade, em todas as dimensões, 
concebida em sua totalidade, mas da qual se elegem um ou mais detalhes para representar, utilizando as convicções artísticas e convenções estéticas específicas de cada época.

Poder-se-ia argumentar, como fazem as teorias mais ligadas unicamente às sutilezas textuais, que existe uma insuficiência do real - empresto o termo de Clement Rosset (1989:14) -, pois o real é amplo demais para ser representado, tal como sugeriram as várias vanguardas do início do século passado, que o colocaram sob suspeita. Evidentemente subjazem aí questões a que só a filosofia poderia dar respostas satisfatórias e é nesse ponto que as considerações de Rosset importam; ele afirma que a verdadeira dificuldade de levar em conta o real e apenas o real reside só secundariamente no caráter amplo e incompreensível da realidade; que essa dificuldade repousa antes de tudo em seu caráter doloroso. Em suas palavras (1989:17):

Suspeito muito que a desavença filosófica com o real não tenha por origem o fato de que a realidade seja inexplicável, considerada apenas em si mesma, mas sim o fato de que ela seja cruel e que consequentemente a ideia de realidade suficiente (...) constitui um risco permanente de angústia e de angústia intolerável.

Essa "ideia de realidade suficiente" engloba, para ele, a apreensão de todos os aspectos do real, sem máscaras, por mais horríveis que sejam, até a dor e o dilaceramento.

Por "crueldade" do real entendo, em primeiro lugar, é claro, a natureza intrinsecamente dolorosa e trágica da realidade. (...) Mas entendo também por crueldade do real o caráter único, e consequentemente irremediável e inapelável desta realidade - caráter que impossibilita ao mesmo tempo 
conservá-la à distância e atenuar seu rigor pelo recurso a qualquer instância que [seja] fosse exterior a ela (1989:17).

Na contramão das análises que descartam a representação realista, com base no conceito de crueldade, tal como exposto - neste nada falta, ele se basta, por isso se impõe sozinho e não se pode atenuá-lo - creio que esse realismo pode estar desempenhando uma espécie de válvula de escape para a angústia da extrema suficiência do real, da sua onipresença e crueldade intrínsecas. Isso porque, como assunção estilística, representa o ponto de tensão inescapável no qual se entrecruzam hoje as linhas da desigualdade, da tecnologia e do espetáculo que compõem a paisagem brasileira, desenhada com a destituição dos valores que não sejam os do mercado e do prazer imediato. Dramatizando o mal-estar gerado pela desgastada crise da tradição e da representação, transformadas pela proliferação de recursos imagéticos e fantasmáticos, parte significativa da ficção contemporânea, não só brasileira, procurando se desviar dos padrões realistas, acaba por reencontrá-los, contraditoriamente, com outras posturas $e$ métodos (Pellegrini, 2007), como resultado da tentativa constante, mas frustrada, de atenuação da crueldade do real. Assim, seu resultado tem sido estetizar a desmedida, mergulhando na crueldade, como forma sutil e sedutora, encenando até um aparente compromisso com a transformação do real que, na verdade, não existe e, se existe, é sempre postergado. Este é meu principal ponto de interesse.

Tornando-se diretriz da organização formal de tantos e tantos textos, a dramatização do princípio de crueldade acima definido, no tipo de narrativa que aqui interessa, entende-se como impiedosa desumanização, embutida em imagens de promiscuidade, perversão, truculência e sangue, escancaradas ou sutis, diretas ou indiretas. Dir-se-ia que, salvaguardadas as óbvias diferenças, dadas por cada contexto histórico, isso ocorre em termos aproximados aos dos primeiros realistas franceses, que 
escandalizaram a moral vigente com suas flores do mal. A diferença é que, então, muitas vezes se conclamava, além dos aspectos estéticos, funções políticas, morais e éticas, pois se procurava elevar o povo à dignidade da representação artística, estabelecendo um pacto com a transformação da realidade. Já afirmei em outros textos que, em termos de sua função não só estética, o realismo foi o que de melhor a burguesia conseguiu produzir naquele momento.

Hoje, ao contrário, percebe-se nas formas realistas em vigor, um alto grau de valorização de cenas de violência e crueldade per se e, ao contrário do que advoga Rosset, para quem "a dureza da coisa não impede a coisa de ser indiferente aos que ela atormenta" (1989:27), sendo que, por isso mesmo, pode e deve ser representada, acredito que esse excesso pode redundar, no plano político mais amplo, que inclui cidadania e direitos humanos, na naturalização das várias formas de violência e autoritarismo. Em artigo sobre a produção cinematográfica atual, em que a mesma tendência prolifera e se espraia, Vitor Hugo Adler Pereira (2004:34) oportunamente considera:

A justificativa, um tanto ingênua, da exposição obscena da violência, em qualquer contexto, como um exame identificado com a busca das verdades secretas do ser humano, acaba por oficializar essa compulsão a tudo mostrar, a tudo dizer, na cultura contemporânea, paralisando a investigação crítica sobre suas implicações. O discurso crítico se omite ou se torna cúmplice da espetacularização da violência.

Têm-se assinalado com insistência o fato de que a violência e a crueldade têm sido a viga-mestra da organização e funcionamento da nossa própria ordem social, simbolicamente figurada na história e na tradição da literatura nacional; de fato, a 
tendência exacerbada de apresentá-la hoje de modo absolutamente verista é um dado sintomático das peculiaridades do processo excludente da modernização capitalista que aqui se cumpriu. Ou seja, questões históricas e sociais não têm apenas uma relação com os textos; eles os constituem e lhes dão forma. Aceitando a premissa de que os antagonismos não resolvidos da realidade reaparecem nas obras de arte como problemas imanentes de sua forma, a proposta aqui é considerar, portanto, nos textos escolhidos, como sua organização formal, em termos de um realismo violento e cruel, corresponde às especificidades sociais do Brasil contemporâneo, ou seja, a um conjunto de formações e situações complexas, que se rearticulam simbolicamente nos textos ficcionais .

Tenho assumido o realismo, nos termos de Raymond Williams (2001), como um tipo de narrativa que cria e atribui valor às especificidades e detalhes de um modo de vida, em termos das características particulares dos indivíduos, conferindo o mesmo valor ao conjunto da sociedade de que eles fazem parte. Creio assim enfatizar a organização e o amálgama de diversas modalidades de experiência representadas: individual e social, subjetiva e objetiva, reflexiva e prática, pessoal e geral, uma refletida na outra, de modo a compor uma visão do todo, que, por sua complexidade e historicidade, não é homogêneo.

Desse modo, se violência e crueldade são dados significantes também da constituição da realidade figurada, englobando tanto o individual quanto o social, em primeiro lugar, ela não pode ser explorada como totalidade fechada, que em seus próprios termos se encerra; depois, ela deve ser articulada de acordo com uma perspectiva ética, que exclui o sentido de mal necessário que se possa atribuir ao conjunto de um enredo, com a justificativa da crueldade intrínseca do real ou de sua correspondência fiel ao estado da realidade brasileira. 
Para Jaime Ginzburg (2012:135), que retoma Adorno, uma perspectiva crítica da violência pode ser obtida não apenas pela tematização, mas pelos modos como se relacionam tema e forma, por meio de "antagonismos formais":

Por antagonismos formais devemos entender situações de incorporação à forma artística de um impasse, de uma negatividade constitutiva, em que a forma de uma obra, em termos estilísticos e historiográficos, entra em confronto com as tendências hegemônicas de produção cultural, bem como com os valores ideológicos dominantes.

Ou seja, a negatividade constitutiva adorniana é justamente a negação do status quo, o enfrentamento das forças que hoje controlam o mundo: a supremacia do mercado, a hegemonia das redes tecnomidiáticas e a assumida impotência do sujeito ante a potência da administração da sociedade.

\section{A suficiência da linguagem}

Tentando elucidar melhor os argumentos esboçados acima, selecionei dois contos de Marcelino Freire, cuja obra pode ser analisada de acordo com os vários aspectos até aqui expostos. É conhecida a trajetória do escritor que, ao lado de Marçal Aquino, Marcelo Mirisola, Fernando Bonassi e outros, integram o grupo no início chamado “Geração 90"2 , cujas características temáticas e estilísticas guardam semelhanças entre si: economia cinematográfica da linguagem, oralidade, fragmentação, erotismo obsessivo e

\footnotetext{
${ }^{2}$ Esses autores obtiveram bastante notoriedade a partir de duas coletâneas de contos organizadas por Nelson de Oliveira: Geração 90: manuscritos de computador (2001) e Geração 90: os transgressores (2003), ambos com o subtítulo de "Os melhores contistas brasileiros surgidos no final do século XX", publicadas pela Boitempo Editorial, de São Paulo.
}

Brasiliana - Journal for Brazilian Studies. Vol. 3, n.1 (Jul. 2014). ISSN 2245-4373. 
desregrado, atribulações e neuroses urbanas, ênfase no grotesco, violência, crueldade e morte, temperados com um certo lirismo sujo e diluído, aspectos esses a que se pode, genericamente, aplicar o rótulo de realistas. Os contos escolhidos pertencem, respectivamente, ao primeiro livro publicado por Freire, Angu de sangue (2000) e ao último, Amar é crime (2010). Em mais de dez anos transcorridos, o autor continua fiel ao seu estilo e à matéria de que se nutre. Não se pode perder de vista que o passaporte para ingressar definitivamente no seleto grupo dos "novos", criado pela crítica jornalística e referendado por parte da acadêmica, foi o "Prefácio" a Angu de sangue, escrito pelo professor João Alexandre Barbosa (2000 :11), no qual ele se detém nos aspectos estéticos, enfatizando o uso da oralidade como o recurso que autoriza o autor a falar sobre a violência sob um outro prisma:

A sua oralidade é de uma espécie mais rara, embora, como escolha e técnica narrativas termine por responder, certamente, à pungência de significados veiculados por alguns desses contos, uma vez que o narrador cede, nesses casos, o seu lugar a uma voz narrativa entroncada em camadas sociais herdeiras da tradição oral.

E considera o fato de que essa oralidade resulta da adaptação a que são forçadas muitas personagens do autor, egressas do mundo rural e mergulhadas na vida turbulenta das cidades. De fato, não é demais lembrar que a imaginação literária das últimas décadas tem sido predominantemente urbana, construindo-se em conjunto com os processos sociais de êxodo rural e crescimento desordenado dos grandes centros, com as consequências da guetificação dos subúrbios e periferias, propiciando o surgimento de grupos isolados com registros e dicções próprias, correspondente à emergência dolorosa de novas subjetividades, gestadas na miséria e exclusão. A essa transformação da malha 
social urbana e rural correspondem, portanto, mediações ficcionais próprias, nos mais diferentes registros, entre os quais se destaca a oralidade.

Ora, a presença desse recurso como tentativa de conferir fidedignidade ao que se narra, ou seja, para introduzir um toque etnográfico-documental de caráter realista no relato, tem sido uma estratégia muito usada na ficção brasileira, desde os "regionalistas" ou "sertanistas" da virada do século XIX para o XX, quando já se procurava diminuir a distância estética entre o narrador e a matéria de que se servia. O modernismo retomou a tendência, combinando-a com a fragmentação, num amálgama que aplicou o carimbo da identidade formal ao período. A diferença hoje reside apenas na multiplicidade de "falares" gerada pelas próprias transformações da língua ao longo do tempo, que inclui registros específicos de comunidades pobres, dos becos, morros e calçadas, entremeadas a expressões geradas e divulgadas pela tecnologia e pela cultura industrial, num conjunto a que se pode chamar de polifônico, seja ou não em sentido bakhtiniano.

Esse "realismo linguístico", que inclui o uso acentuado de rimas de todos os tipos, salpicadas no relato como a conferir ironicamente um toque poético contrastivo à matéria brutal, é a marca registrada de Marcelino Freire, já assinalada muitas vezes pela crítica em geral, que, talvez também pelo excesso desse recurso - e de outros -, tem dedicado a ele muitas resenhas, análises e interpretações. ${ }^{3}$ Todavia, é preciso dizer, esses recursos propiciam ao leitor, interessado no "retrato da realidade brasileira" e perplexo com sua brutalidade, a oportunidade de desviar a atenção para o discurso, minimizando assim a contundência da matéria que o enforma, embora ela mesma seja representada

\footnotetext{
${ }^{3}$ As resenhas e análises, todavia, não são unânimes nas considerações. Encontram-se, junto aos elogios, críticas bastante ácidas. Ver, por exemplo: Ginzburg, Jaime. "A violência em um conto de Marcelino Freire”. Letras de hoje. Porto Alegre, v. 42, n.4, p. 42-48, dez. 2007 e Lísias, Ricardo. "Prosa faz injustiça social parecer exótica”. Entrelivros. Ano I, no. 4, p. 72.
} 
por meio de um repertório já previsível ${ }^{4}$ de situações de sangue e tormento físico, com figuras de crianças abandonadas, prostitutas, mendigos e outros rejeitos que a sociedade cospe ou encarcera. Como considera Flora Sussekind (2005:63), “a ampliação da área de visibilidade urbana (...), parece corresponder, em parte, nesses casos, a uma restrição narrativa e crítica, a uma reafirmação da distância entre observador e matéria documentada, a um controle e imobilização da perspectiva histórica".

Se, como afirmamos acima, uma perspectiva crítica da violência se consegue não somente pelo tema escolhido, mas pelos modos como tema e forma estão relacionados, por meio de "antagonismos formais", o que evidenciaria uma perspectiva ética, que se recusa à aceitação da citada suficiência do real e também da suficiência da linguagem, cabe verificar então se essa perspectiva efetivamente se aplica à literatura de Freire.

\section{Escrever sob violência}

Como já há tempos a visibilidade é um dos elementos fundamentais de divulgação de escritores e obras, é sempre interessante, como um elemento a mais para amparar a reflexão crítica, dar voz ao próprios autores. Em entrevista ao portal Cronópios ${ }^{5}$, Freire afirma :

Costumo dizer que eu não escrevo "sobre" violência. Escrevo "sob" violência. Dizem sempre que meus contos são violentos, meus personagens são todos doentes. Doentes estamos todos, ou não? O nosso

\footnotetext{
${ }^{4}$ Desde o surgimento de Cidade de Deus (Paulo Lins, 1997), Estação Carandiru (Dráuzio Varela, 1999), Capão Pecado (Ferrez, 2000) e outros, tem-se multiplicado esse tipo de relato, muitos deles com claras conotações de pastiche.

${ }^{5}$ www.cronópios.com.br/site/artigos.asp?id=1943 (Acesso em 22/11/2011).
}

Brasiliana - Journal for Brazilian Studies. Vol. 3, n.1 (Jul. 2014). ISSN 2245-4373. 
tempo é doente, violentamente. Eu sou um escritor deste meu tempo, do aqui e do agora. Quem quiser "felicidade", "conforto", não vá ler os meus livros. Vá atrás de autores de autoajuda. E mais: dizem idem que eu só escrevo sobre gente mal-sucedida. Eu respondo: eu não estou preocupado com gente bem sucedida. Meus livros não são empresariais. Eu faço é literatura, entende?

Com efeito, não há como negar o esforço do autor, ao longo de sua obra, de buscar a voz dos deserdados, seu lugar de fala, quem sabe uma possível forma de resistência - o benefício da dúvida - em meio à tragédia social brasileira e ao lixo cultural; mas seu empenho nem sempre tem produzido resultados que fogem do que se tem chamado, a torto e a direito, de banalização da violência na ficção atual ${ }^{6}$.

Sob violência vive J.C.J., o menino de rua de um conto de Angu de sangue, cujo título é exatamente esse: J.C.J. Como todos os outros contos do livro, a primeira linha deste está impressa em vermelho; "há uma gota de sangue em cada poema”, dizia Mário de Andrade, mas a constatação aqui é de outro tipo. Talvez uma advertência sobre o que o leitor vai encontrar em seguida; aliás, todos os contos têm essa característica, recurso óbvio para realçar o significado também óbvio do título.

Trata-se da narrativa do assalto a uma mulher dirigindo um carro, que para em um sinal fechado. J.C.J., moleque de rua, empunhando um caco de vidro, corta-lhe a garganta, rouba-lhe o relógio e foge. Várias pessoas em volta gritam por socorro, atônitas, enquanto sob o sol, o trânsito histérico buzina. Um frentista de posto de gasolina, parecendo acudir, furta-lhe da bolsa dinheiro e documentos; enquanto expira, a mulher tem pensamentos desencontrados e a cidade ruge em volta, indiferente. Tudo

\footnotetext{
${ }^{6}$ Marcelino Freire escreveu, depois de Angu de sangue, BaléRalé (2003), Contos Negreiros (2005), Rasif - mar que arrebenta (2009) e Amar é crime (2001).
} 
rápido, eficiente e fatal, em três páginas de contundência atroz: "Deus, Nosso Senhor, o menino nem tinha tamanho" (Freire, 2000: 126).

$\mathrm{Na}$ intermitência dos vocábulos, lampejos, flashes, a luz do sol, o calor do asfalto, o brilho do vidro, gritos, vozes, o sangue, o suspiro, a morte. Nessa vertigem, giroscópio, video game, que colocam o leitor no centro do crime, chama a atenção, por contraste, a marca facilmente observável em todos os textos da coletânea: o ludismo verbal, o jogo sonoro-semântico e os recursos gráficos que pretendem sustentar a narrativa. Esse jogo, que não raras vezes produz efeitos dignos de nota, de fato luminosos, na maior parte das vezes parece esvaziado de sentido, o que lhe rouba o caráter de um possível antagonismo formal, de uma exigência real da matéria, como apontei acima. Vejamos:

Adolesce o menino de rua, o menino cheirado à cola, sem sapato e sujo. Droga mole. Amola, esmola todo dia todo santo carro. À mulher do carro ele se chega, reto e disforme em direção. Ela não sabe e abre a janela para a morte, abre a janela para dizer um palavrão (espaço para sugestão:.

.) (2000:123).

Mimetizando o ritmo nervoso da cidade empilhada, desde o início, o confronto, a violência e a crueldade são transferidos para a organização da linguagem, que, apesar do impacto do "real", além de ser manejada com sutilezas de um poema, sujo embora, pretende estabelecer com o leitor um pacto de leitura calcado na possibilidade de decifrar alguns códigos, o que atropela a interlocução e a eficácia da intenção, crítica à primeira vista, pois Freire "escreve sob violência", como diz . Apesar disso, o exercício 
lúdico, que inclui inversões sintáticas, rimas, ritmos e soluções copiadas da cultura de massa, em contraste com o peso da matéria, introduz uma nota de frivolidade, acentuada com a ironia vazia do "espaço para sugestão".

“Quero moeda, mocreia" - diz J.C.J. - tava ele uma pistola.

Ela diz que não tem, amém e merda, e mostra uma cara, gorda cara, e uma língua pastosa que não sabe quanto custa cuspir na cara de alguém. Mesmo alguém assim fininho, mesmo alguém assim desalguém.

E ladra: "Não vem, nem vem, não vem. Que não tem, não tem, não tem" (2000: 123-4).

No conjunto dos textos de Freire, comumente diálogos breves e certeiros, como tiros ou facadas, substituem a narração, constituindo uma junção aleatória de discursos, que saltam constantemente do direto para o indireto livre, estabelecendo-se assim uma ambiguidade discursiva que, de propósito, oblitera a comunicação. Quem narra? Quem fala? Quem pensa? Quem vê? O efeito de transgressão das barreiras de significação, que revitaliza a estrutura dialógica, talvez tenha a intenção de tentar transferir para a linguagem a violência da própria estrutura social - de novo, o benefício da dúvida -, buscando escapar do método descritivo tradicionalmente usado pelo realismo, que em geral procura expor cada minúcia do que pretende representar.

Ainda vê o menino na dobra da esquina. Ele corre, pequeno, já sumindo. $\mathrm{O}$ que ele viu nela? Nem veste-se mais suntuosa. A cada dia mais engorda. A cada mais nervosa. A cada dia mais de menos. O cinto de segurança tomando-lhe o decote e o oxigênio. Olhos the atropelam. O que foi? Se foi. Ela aponta, tonta. O menino nem nem (2000: 123- 4). 
Nas duas primeiras frases pode-se identificar o narrador em terceira pessoa, mas na seguinte, "o que ele viu nela?", sobrepõem-se a fala do narrador e o pensamento da personagem feminina, de modo que não é possível distingui-los, recurso que continua por todo o fragmento, até nova intromissão clara do narrador, "olhos lhe atropelam"7, indicando o surgimento de outras pessoas que perguntam "o que foi?". "Se foi" pode ser a resposta da personagem em relação à fuga do menino ou uma notação de dúvida em relação ao ocorrido: foi mesmo alguma coisa? E o narrador em terceira pessoa reaparece nas duas últimas frases.

Esse esboço de "análise de discurso" faz-se necessário para evidenciar a estratégia narrativa e as soluções expressivas do autor, que não são exclusivas ou originais, como disse, podendo ser encontradas em muitos outros escritores voltados para temas semelhantes, sobretudo em narrativas curtas, como se a dureza da matéria de fato não suportasse outros voos. Nesse sentido, é emblemático o título do conto, carregado de ironia: J.C.J., que é o nome do moleque. Ao que tudo indica, trata-se de uma alusão às letras inscritas na cruz de Cristo, JCRJ (Jesus Cristo Rei dos Judeus), o que autoriza intuir uma empatia do narrador (e do autor) para com o menino assaltante, visto como mártir da infância crucificada pela sociedade injusta, "doente". Além disso, a ilustração que abre o $\operatorname{conto}^{8}$, uma tarja preta no meio da página branca, insinua que a identidade do pequeno assassino ( ele apenas adolesce), deve ser preservada; assim, ele não tem nome, apenas iniciais, tal como não têm nome, em geral, quase todos os personagens de Freire.

\footnotetext{
${ }^{7}$ Note-se o emprego do pronome lhe.

${ }^{8}$ Todos os contos do livro, nessa $1^{\text {a }}$. edição, abrem com imagens significativas: insetos, esqueletos, pássaros mortos, rostos humanos, cuja análise poderia constituir material de interesse.
}

Brasiliana - Journal for Brazilian Studies. Vol. 3, n.1 (Jul. 2014). ISSN 2245-4373. 
O uso do nome de Cristo, ironicamente em vão, procura elaborar, como toda a arquitetura do conto, um viés transgressivo também com relação aos grandes relatos, a religião, a história, a ciência - conforme postula a crítica pós-moderna - que tentam explicar e organizar em um todo racional o mundo tido como completamente inapreensível e inexplicável. Que alternativas restam para a mulher e o menino, abandonados por Cristo? No reino do Mal absoluto, só a violência, a crueldade, a morte, de fato a suficiência do real, indiferente à dor e ao dilaceramento que pode causar: “Sozinha e Deus, nos giros dos pneus" (2000:124).

Nessa direção, é importante notar que enquanto o menino aparece como "mártir", à mulher parece caber o papel de culpada pela situação política e social: “...vota: em quem? Partido da situação não toma" (2000: 123). Para ela, o narrador não concede nem uma gota de piedade, acentuando apenas traços grotescos e pejorativos, em evidente maniqueísmo: “cara, gorda cara", "língua pastosa” (2000:123), "mole, que nem toda mulher de bem"; "A cada dia mais engorda. A cada dia mais nervosa. A cada dia mais de menos"( 2000: 124).

A análise do conto parece conduzir à constatação de que devido ao choque causado pelo relato, pelo seu sentido aparente de crítica e acusação, pela transgressão dos limites da representação, o leitor é sacudido de sua passividade, abalado em suas certezas e chamado a um posicionamento, quando não político, pelo menos solidário. Mas, na verdade, devido aos próprios artifícios linguísticos e à organização do relato, evidencia-se um maniqueísmo apolítico, em que o mal está nos ricos e o bem nos pobres, sublinhando uma incapacidade de tentar negar a desumanização e a violência e caindo no absoluto niilismo, pois a suficiência do real impede qualquer movimento diferente. Não se desenha assim nenhum antagonismo formal em relação ao realismo tradicional, apesar dos jogos expressivos vazios (repetições, assonâncias, aliterações, pontuação livre e lúdica, etc.), pois o mundo representado é uma totalidade fechada, suficiente em si 
mesmo, sem fissuras que lhe possam abalar a arquitetura. A conexão com o vivido da experiência histórica e social, que existe, e o cuidado na objetivação da narrativa de teor testemunhal não conseguem evitar um sentimento de absurdo causado pelo real contundente que se expõe, como mais uma mercadoria na vitrine já cheia de produtos como esse.

\section{A abjeção e o Mal}

O outro conto escolhido para análise pertence à coletânea Amar é crime na qual o conjunto dos textos denota a reiteração, com pequenas variações, dos mesmo aspectos apontados no primeiro livro, ou seja, Freire continua a escrever "sob violência", utilizando os mesmos recursos, alguns deles aqui exacerbados. O que chamou minha atenção para o conto "Liquidação" (Freire, 2010), que tentaremos analisar, na mesma perspectiva, é a semelhança do seu tema com um outro de Marçal Aquino, de título "Boi" (Pellegrini: 2012).

Em ambos temos como personagens moradores de rua que se enfrentam até a morte na luta por sua quota de miséria. Lá, o móvel da disputa é um barraco debaixo do viaduto; aqui, é um sofá atirado na rua, num canto qualquer da cidade indiferente, que dois Homens da Carroça querem para si. O primeiro, que o prometeu ao filho pequeno, diz que o reservou no dia anterior, amarrando-o com cordas; o segundo não aceita o argumento, que ali naquela terra de ninguém não faz sentido. Propõe uma sociedade no sofá, recusada. Atracam-se, "foi juntando um povo em volta" (Freire, 2010:84), uma faca aparece e ali jaz o corpo estendido, em meio a uma poça de sangue. Enquanto isso, a Mulher do primeiro Homem da Carroça, apreensiva, espera no buraco escuro onde moram, debaixo do viaduto. O desfecho da luta não é, todavia, o final. 
Neste, que vem logo depois, não fica claro se a disputa e a morte foram fatos "reais", se foi uma premonição da Mulher ou apenas um sonho do Homem da Carroça:

O corpo do Homem da Carroça ali, como se deitado na sala de estar, no centro da cidade, pode?

- Tire esse cachorro aí de cima, mulher!

Ou:

Acorda, Zé, acorda. Vem para cama, homem. Levanta deste sofá.

Quanta folga! Daqui a pouco dá a hora de o Homem da Carroça ir trabalhar (Freire, 2010: 88).

Aliás, o recurso à ambiguidade e também a certo viés mágico ou fantástico não estão ausentes da literatura de Freire, como neste caso, em que a brincadeira com os possíveis finais sugere uma tentativa irônica e fora de lugar de minimizar o teor cruel da narrativa e o quociente de realidade da matéria.

Desde o início, repete-se a despersonalização dada pela ausência de nomes, característica exaustivamente explorada por Freire, como apontei; os personagens recebem denominações referentes apenas ao que fazem nas ruas: são Homens das Carroças, alguns daqueles muitos sem-nome que se arrastam todos os dias pelos monturos, recolhendo restos aproveitáveis que a cidade rejeita (exceto no final, talvez onírico, em que o Zé, nomeado agora, passa a ser "alguém”). Só o filho do protagonista tem um nome, que não é seu, Hering, a conhecida marca retirada da "camisa 100\% suja que o Homem da Carroça usa"(2010: 82), traço que dispensa explicações. São todos personagens animalizados, burros de carga a puxar carroças, insetos a rastejar: “...socava-se o menino entre as pernas do pai. Manobrava um automóvel nas pernas do pai. Toda vez que o pai chegava. Feito barata." (2010:84) 
Esses personagens respiram lixo e podridão e o modo como o narrador os pinta, sem resquício de piedade, parece insinuar que eles se comprazem com essa sordidez e refocilam nela. Por exemplo, a mulher, alimentando premonições sobre o que estará acontecendo com o Homem da Carroça, pensa: "Se o Homem da Carroça morresse, sentiria falta, saiba. Do piolho do Homem. Da porquidão. Sentiria falta da frieira do Homem. Do bicho do Homem (2010: 82). Ou ainda: “Sentiria falta do contágio do Homem. Das exalações. Do abafo do Homem. Nodoamento, podricalho. Da sebentice sentiria falta (2010:84). E também: “Sim, a Mulher sentiria falta, não ache que não. Da putrescência. Caspa. Sentirá falta do muco. Da langanha. Do pingão. Saudade de tirar sujidades dele. De lavar, descaquejar, escovar."(2010: 85).

A insistência do narrador, de novo em terceira pessoa, misturando-se às divagações da Mulher, nos aspectos nauseantes da fisiologia humana, relacionados à vida em condições de extrema miséria, acentua a animalização num nível em que qualquer afirmação de que se escreve "sob violência" ou de que "a sociedade é doente" é um escárnio. O desprezo pelo corpo alheio e o rebaixamento puro e simples do humano, cernes do sadismo, vazados na enxurrada de termos relacionados à imundície, conduzem aos limites da abjeção, que tem sido uma das marcas fortes da cultura contemporânea, não por acaso. As personagens deste conto são, assim, animais abjetos, burros de carga imundos, porcos, baratas, a quem se recusou qualquer traço de humanidade. E nada está ausente do bestiário: “Sim, o Homem da carroça também cria um cachorro. Cachorro não pode faltar" (2010: 83).

Nesse passeio pelo jardim zoológico da ficção, o leitor se vê confrontado, portanto, com os aspectos mais cruentos da realidade, em uma espécie de elogio da miséria, em que o ser humano é abandonado à própria sorte: “Cadê que ninguém aparece? Um advogado, uma prece. Uma salvação, sei lá" (2010:85). Assolados pela penúria extrema, os personagens do conto vivem em sobressalto, em estado de guerra, 
articulando ações cujo único objetivo é tentar suprir a escassez total; isolados e em luta permanente, eles cercam e protegem seu território, pois não havendo a quem recorrer, não se reconhece a posse de nada e o direito à coisa nenhuma. A ação de cada um é limitada apenas pela força do outro; seus atos, unicamente ligados à necessidade de sobrevivência, são ditados por uma espécie de "estado natural" animalesco, em que os horizontes entrevistos são mais miséria, violência e sangue, desde que a única lei válida é a força. ${ }^{9}$ Ninguém pode escapar, insinua o narrador, interpelando diretamente o leitor: “Hering gosta de desenho violento. Quando crescer, você vai ver. O filho do Homem da Carroça não vai deixar barato"(Freire: 2010: 85).

Nada ou ninguém vai retirá-los dessa situação, o que o fragmento acima insinua. Numa sociedade em que os indivíduos são abandonados à própria sorte, o mal prolifera implacável, como parece entender o narrador (o autor?), misturado às vozes de suas criaturas, rejeitando novamente todos os "grandes relatos": "Memória. Pertencimento. História. Iremos juntos ao fim do inferno, diziam. Deus estava vendo. Deus é justo. Quem disse? Deus? Justiça? Inferno? E ria o Outro Homem da Carroça" (2010: 83).

Desse modo, o realismo de Freire de fato atribui valor representacional às especificidades de um modo de vida, mas sem atribuir o mesmo valor ao conjunto da sociedade de que ele é parte. Não existe “a organização e o amálgama de diversas modalidades de experiência representadas, individual e social, subjetiva e objetiva, pessoal e geral, uma refletida na outra", como antes assumi, de acordo com Raymond Williams; o que ele encena quase pornograficamente é a homogeneidade de um conjunto sem qualquer espessura, complexidade ou historicidade.

\footnotetext{
${ }^{9}$ As características hobbesianas aqui descritas já foram enunciadas por mim em outros textos, mas a repetição se justifica porque se trata da análise de autores muito semelhantes entre si na escolha da matéria humana e nas formas de utilizá-la em sua ficção.
}

Brasiliana - Journal for Brazilian Studies. Vol. 3, n.1 (Jul. 2014). ISSN 2245-4373. 
É possível entrever, assim, similaridades entre a visão de mundo hoje dominante, a que Freire dá voz, e alguns dos eixos que sustentam também o pensamento de George Bataille $(2000)^{10}$, tais como a presença necessária do Mal, a ausência de Deus, a ideia de transgressão dos limites e a impossibilidade de comunicação, que desembocam no excesso. Poderíamos aqui enfatizar o excesso de cena, significado também atribuído a "obsceno", centrado na matéria humana abjeta, vazada no estilo fragmentário e desordenado do autor, que angustia e afasta, sem deixar de atrair. Com efeito, essa miséria, essa sujeira, essa falta, esse sangue, esses bichos, esses crimes, tudo se junta para produzir medo e repulsa, mesclados a uma atração insopitável pela negação da nossa humanidade, o que, em última instância, repousa no "caráter único, irremediável e inapelável da realidade" (Rosset, 1989:17).

\section{As tragédias mínimas}

Por suas características de conteúdo e forma, a literatura de Freire e de outros semelhantes, pode, com afirmei no início, significar para o leitor um dispositivo de vazão - um mecanismo até certo ponto catártico, acredito - para o medo e a intolerável angústia despertados pela extrema suficiência do real, vivida a cada dia e sociologicamente traduzida como a "tragédia social brasileira". E, por analogia com esta última expressão, que venho trazendo ao longo deste ensaio, pode-se talvez pensar nesse tipo de literatura como um gênero novo e chamá-lo - com ironia, claro - de tragédias mínimas, centradas no quotidiano das camadas mais desvalidas da população, aquelas para quem o caráter inapelável da realidade não é ficção. Brutalidade, sangue,

\footnotetext{
${ }^{10}$ Bataille, George. La literatura y el mal. www.elaleph.com , 2000. Essa similaridade, apontada em muitos autores da citada "Geração 90", tem sido bastante explorada e constitui uma vertente crítica de interpretação muito atuante. Ver, a propósito: Estéticas da crueldade, cit. A palavra Mal, com maiúscula, aqui é usada nesse sentido.
}

Brasiliana - Journal for Brazilian Studies. Vol. 3, n.1 (Jul. 2014). ISSN 2245-4373. 
torpeza, violência e crueldade seriam traços essenciais de sua constituição e organização formal.

Cruor, de onde deriva crudelis (cruel), assim como crudus (cru, não digerido, indigesto) designa a carne escorchada e ensangüentada: ou seja, a coisa mesma privada de seus ornamentos ou acompanhamentos ordinários, no presente caso a pele, e reduzida assim à sua única realidade, tão sangrenta quanto indigesta. Assim, a realidade é cruel - e indigesta - a partir do momento em que a despojamos de tudo o que não é ela para considerá-la apenas em si mesma (Rosset,1989: 17).

Essa definição de crueldade trazida por Rosset, muito citada, baseada na etimologia da palavra, pode-se assim aplicar ao novo gênero, do qual os contos de Freire são um exemplo, desde que assumem violência e crueldade como estruturantes, servindo-as aos leitores em um cardápio sem variações. De fato, constituindo-se como "tragédias mínimas", poderiam ser tomadas como partículas da grande tragédia social brasileira, a "sociedade doente", como a define o autor, mas não é isso o que acontece; cada uma delas, como já disse, é uma totalidade fechada em si mesma, sem ligação de causa e/ou consequência com o todo maior que a engendra.

Nas “tragédias mínimas" não se tem apenas a representação da violência, do sofrimento e da morte, mas um tipo específico de apresentação desses elementos, que, apesar de si mesmo, pode guardar similaridades com a tragédia literária, cuja ação está centrada na queda de personagens nobres e dignos, como se sabe. Descarto-lhe desde já a sintaxe, que foi alterada, pois aqui não há sujeitos, deuses ou heróis, só objetos, "gente comum" e mendigos em estado de natureza, iguais na miséria transcendente de seres abandonados por Deus. O trágico aqui encenado assemelha-se ao Mal triunfante, à 
vitória total da crueldade, que, todavia, ao invés de aterrorizar, conforta, porque se encarna, como acontece nesse tipo de narrativa, em bodes expiatórios: o menino de rua e a mulher gorda do primeiro conto e os animais que puxam carroças, no segundo.

É preciso considerar também que as experiências e vivências que hoje se podem comumente chamar de trágicas são mais gerais, como incêndios, chacinas, fome e mendicância, com nada da nobreza e dignidade dos eventos sobre os quais repousava o gênero antigo. Isso posto, cabe a pergunta: é possível uma relação entre a tradição da tragédia e as experiências e vivências a que estamos sujeitos em nossa época, e que, no nível simbólico, podem estar representadas nas “tragédias mínimas" de Freire?

Talvez uma resposta resida em uma das maneiras por meio das quais se dá tal relação. Uma delas é a assunção hoje amplamente disseminada da suficiência do real, como ponderei acima, em que até a própria existência é vista como um crime inafiançável. Segundo essa visão, a violência e a crueldade têm raízes na natureza do homem, em relação à qual considerações históricas e sociais são irrelevantes. O que se vê, então, a alimentar as "tragédias mínimas" de hoje é o domínio do acaso, a naturalidade da dor e o triunfo do Mal, contra o que nada se pode fazer; esse gênero novo seria, pois, um lembrete salutar contra qualquer ilusão de que é possível intervir no curso de um destino já traçado.

O Mal assumido como realidade transcendental, produz, em termos de sua representação, segundo setores da crítica, a verdadeira natureza humana, dramaticamente revelada, contra todas as ilusões anteriores de civilização e progresso. Desse modo, a totalidade fechada que constitui o universo restrito, por onde circulam os personagens dessas "tragédias mínimas", são territórios tomados por ele, sem que se vislumbre a causa de seu surgimento e conformação e muito menos suas consequências, além da destruição e da morte, pois isso não importa. 
Todavia, contra a ideia deste "Mal necessário", niilista e iniludível, Raymond Williams considera: “O que é apresentado como significação trágica é aqui, como em outra parte, uma significativa recusa da possibilidade de qualquer sentido" (2002: 85). Haveria, então, um certo encanto em aceitar a análise das narrativas de Freire à luz dessas concepções, aliadas ao aporte cinematográfico ${ }^{11}$, ao apuro técnico da linguagem, aos jogos de palavras, às rimas, à conjunção de focos narrativos, aos diálogos rápidos e certeiros, como tem sido comum. Porém, "se as palavras importam, os sentidos também terão importância, e ignorá-los formalmente significa, de maneira geral, aceitar alguns deles informalmente" (Williams: 2002: 87).

Nessa linha, o reconhecimento da presença da violência e do mal - qualquer mal como matéria representável, não pode implicar sua aceitação como transcendente ou inescapável, devido à suficiência do real postulada por Rosset, nem como inerente à natureza humana, como aventava Schiller no século XVIII; deve implicar sua negação, para que não sejam legitimados ou banalizados também fora da esfera da representação. Dito de outra maneira, a violência e seus corolários não podem submeter o campo estético, pois isso seria abrir mão da possibilidade de oposição à própria barbárie que este pode representar.

No entanto, do mal é preciso falar, como argumenta Maria Rita Kehl ( 2000: 145), pois falar reduz sempre o objeto à dimensão humana: "traz para perto do nosso alcance, em partes menores forçosamente, o absoluto que nos oprime“. Mas ela entende também que:

(...) nesse ponto se coloca um problema ético: se o mal é representável, como falar dele sem produzir o efeito de um gozo? A pretensão de dizer

\footnotetext{
${ }^{11} \mathrm{O}$ estilo de Freire tem sido comparado ao dos filmes de Tarantino, guardadas as diferenças das linguagens. Essa comparação renderia muito se focasse mais na dimensão cínica que as formas expressivas de ambos compartilham.
} 
tudo - ir até o abjeto (...) não é uma tentativa de promover o gozo na abjeção? Afinal, o que fica de fora, num texto, nem sempre é o indizível. (...) é o ponto onde o escritor escolheu recuar. A renúncia à pretensão de "dizer o real todo" produz outra linha de estilos (...) e outra ética também: a que consiste em implicar o leitor na continuação da escritura e responsabilizá-lo através do pensamento.

Assim, a carne escorchada e ensanguentada que se serve ao leitor, recoberta por uma pele de palavras em engenhosas combinações, não se apresenta como um antagonismo formal, mas como pura pretensão de "dizer o real todo", que aí mesmo se esgota. Na verdade, como lúdico deleite, aperta em mais uma volta o parafuso, elevando gozosamente a requintes de crueldade a violência: sutileza na aplicação, cuidado nas minúcias, argúcia na escolha dos métodos, apuro e cálculo na elaboração, como sublinhei no início. Ao contrário de uma visão negativa, que rejeita o real, o autor reitera um viés afirmativo e conformista com relação à "carne" de que se farta, imbuído de um ceticismo regressivo em que não há lugar para a verdadeira complexidade da experiência humana e social, mas que pode coruscar como um artefato a mais nas vitrines da contemporaneidade brasileira. Essa é, pois, sua função. Em síntese, Freire parece acreditar que uma leitura cínica da tragédia social brasileira pode ser estimulante e até reconfortante; seria melhor, assim, se faltasse sempre uma palavra.

\section{Bibliografia}

Barbosa, João Alexandre. "Prefácio". Freire, Marcelino. Angu de sangue. São Paulo: Ateliê Editorial, 2000.

Bataille, George. La literatura y el Mal. Ediciones Elaleph.com , 2000. 
Dalcastagnè, Regina (Org.). Ver e imaginar o outro - Alteridade, desigualdade, violência na literatura brasileira contemporânea. Vinhedo: Horizonte, 2008.

Dias, Ângela M. e Glenadel, Paula. Estéticas da crueldade. Rio de Janeiro: Atlântica, 2004.

Eagleton, Terry. Sweet Violence - The Idea of the Tragic. Oxford: Blackwell Publishing, 2003.

Eco, Umberto. História da feiura. Rio de Janeiro: Record, 2007,p220..

Freire, Marcelino. Angu de sangue. São Paulo: Ateliê Editorial, 2000. . Amar é crime. São Paulo: Edith, 2011.

. "Belinha". Angu de sangue. São Paulo: Ateliê Editorial, 2000.

. Cronópios . www.cronópios.com.br/site/artigos.asp?id=1943

Ginzburg, Jaime. Crítica em tempos de violência. São Paulo: Edusp/Fapesp. 2012.

.. "A violência em um conto de Marcelino Freire". Letras de hoje. Porto Alegre, v. 42, n.4, dezembro de 2007.

Hooks, Bell. "Cool cynicism: Pulp Fiction". Reel to Real - Race, class and sex at the movies. New York and London: Routledge, 1996.

Kehl, Maria Rita."O sexo, a morte, a mãe e o mal". Nestrovski, A. e Seligman-Silva, M. Catástrofe e representação. São Paulo: Escuta, 2000.

Lísias, Ricardo. "Prosa faz injustiça social parecer exótica". Entrelivros. Ano I, no. 4, p. 72.

Pellegrini, Tânia. " Realismo: postura e método". Letras de hoje. Porto Alegre, v. 42, n.4, dezembro de 2007.

. "De bois e outros bichos: nuances do novo realismo brasileiro". Estudos de literatura brasileira contemporânea, n. 39 - Brasília, janeiro/junho de 2012. 
Pereira, Vitor H. A. "A lei do silêncio da violência". Dias, Ângela M. e Glenadel, Paula (org.). Estéticas da crueldade. Rio de Janeiro: Atlântica Editora, 2004.

Rosset, Clément. O princípio da crueldade. Rio de Janeiro: Rocco, 1989.

Sussekind, Flora. "Desterritorialização e forma literária: Literatura brasileira contemporânea e experiência urbana". Literatura e Sociedade. São Paulo, v.8, 2005.

Williams, Raymond. Marxismo e literatura. Rio de Janeiro: Zahar Editores, 1979. . The Long Revolution. New York: Broadview Press, 2001. . Tragédia moderna. São Paulo: Cosac Naify, 2002. 